\title{
MORPHOLOGY OF FOLKLORE BATU NAGA LAMPUNG
}

\author{
Sri Nursari, Slamet Subiyantoro, Kundharu Saddhono \\ Graduate Program in Indonesian Language Education, Universitas Sebelas Maret, Surakarta, Indonesia \\ Jalan Ir. Sutami Nomor 36 A, Jebres, Surakarta, Indonesia \\ Corresponding Author: srinursari@student.uns.ac.id
}

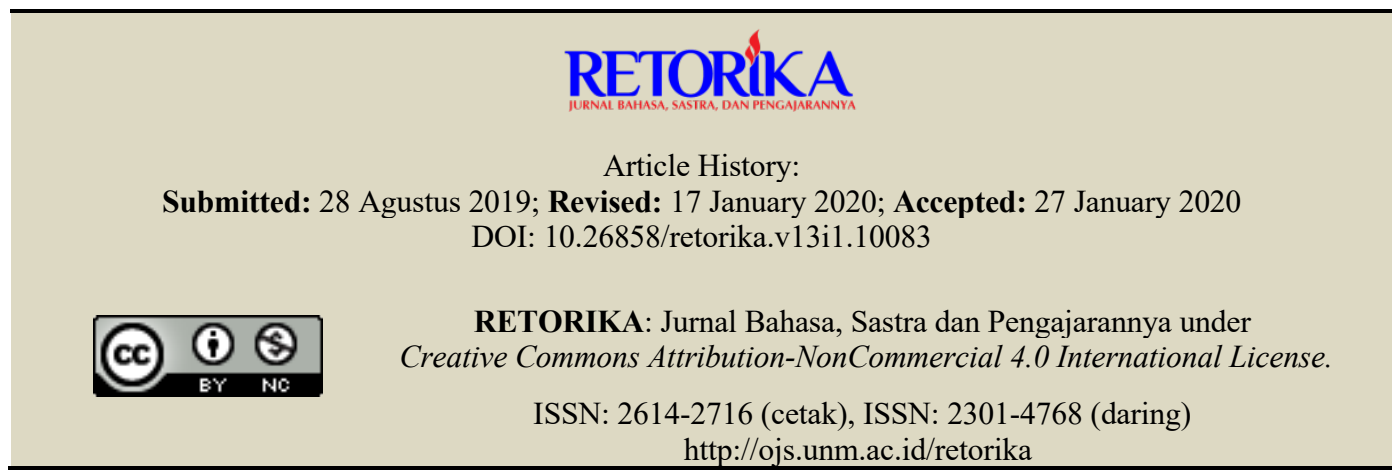

\begin{abstract}
The purpose of this study was to analyze the morphology of folklore based on Vladimir Propp's theory and method of researching Narratology structure including the structure of the actor's action function, the function in the action environment, and the scheme. This research method is descriptive qualitative and the method developed by Vladimir Propp. The object of research is the Batu Naga Lampung folklore. The technique of data collection is done by the documentation technique through a literature study. Data analysis techniques use the flow method that is data reduction, data presentation, and concluding. The results of the study found there are 26 functions of the perpetrators' actions that are distributed into 6 action environments.
\end{abstract}

Keywords: folklore, narratology, Vladimir Propp, Batu Naga

Language is an arbitrary and conventional symbol of sound that is used by the community as a means of communication, interacting, working together. Without human language will have difficulty in socializing with the environment. Language is a symbol of people's culture in communicating and affirming their collective identity. Language and culture influence each other and have a reciprocal relationship. Language creates a culture that is owned by humans, otherwise, culture can affect the language used by humans. Matsumoto and Juang (in Sarwono, 2016: 60) say language and culture have reciprocity, it is shown that every culture cannot be understood without first understanding the language, and vice versa.
Culture has a tradition handed down by ancestors from generation to the next generation it can take the form of oral literature. Oral literature can be in the form of folklore into an inheritance inherited from generation to the next generation (Hamik, 2018). As a speech, folklore works through a combination of various qualities of the human voice (Putra \& Wahyuningtyas, 2017). Folklore is defined by Endraswara as part of traditional culture that has been carried down through generations with different versions, namely oral, movement or with other tools (2013:2).

Haviland (1988: 2228) divides folklore into three categories namely myths, legends, and fables. Simply stated again by Anderson (2006: 
63) the definition favored by folklorists is in terms of belief: myths can be believed, legends carry at least a shadow of a doubt, and folklore or fairy tales are regarded as fiction. Folklore consists of stories that are told to become an important cultural heritage (Maneerat and Wilailak: 2012). Each story has a structure or pattern that can form a story in its entirety, easy to understand, and can be studied. To be easily analyzed, the existing documents need documentation so that the stories are not lost.

Oral literature that has begun to disappear is Lampung oral literature. Not many people know the folklore that is still connected and remains today. The community is less concerned with ancestral heritage and there is no action to preserve, for example, the story of Batu $\mathrm{Na}$ $\mathrm{g} a$ from Lampung. Oral literature is almost extinct, no one cares about the content and meaning of the story. Even though the Batu Naga story has a history, the values of character, have a relationship with the life around the story that originated. The existing history is only known by old people before, not today's young generation. To revive oral literature that was almost extinct, this research was conducted.

Because oral literature is anonymous (the author is unknown), oral literature can change in terms of both the addition of stories and the reduction of stories. However, each structure of the story has in common that is having characters who play a role in the story. In addition to characters, the story also has a plot and pattern to arrange the course of the story intact.

The structure or pattern contained in the story which becomes a unity contained in narrative discourse. The study of narrative discourse is considered to involve language, literature, and culture concerning humanitarian science objects (Bal, 1999: 119). Vladimir Propp is a character who concludes that all stories have the same structure. That is, a story of the perpetrators and their nature can change, but the actions and roles are the same (Ratna, 2012: 132). In the narrative structure, the most important thing for Propp is not the characters but the actions of the characters hereinafter referred to as functions (Rokmansyah, 2014: 92). Propp conducted his research on a hundred Russian fairy tales which summarized that each story has a character to occupy a particular function in the story. Then the research was written and recorded in the title Morphology of the Folktale by producing 31 functions that are distributed in 7 action environments that can be described in the scheme.

Morphological research of folklore departs from a Russian formalism figure, Vladimir Propp. Born in St. Petersburg, Germany on April 17, 1895, and died August 22, 1970. Vladimir Propp was a pioneer of research in the field of narratology. The narratology of the word narratio (Latin means story, word, story, saga) and logos (science). Narratology is also called narrative discourse (text) theory. Both narratology and narrative discourse (text) theory are defined as a set of concepts about storytelling and storytelling (Ratna, 2015: 128).

The purpose of narratology is to study literary works in the form of discourse (Sehandi, 2014: 113). The main attraction of narratology theory is how discourse gives rise to a story that has a plot (Abrams, 2009: 209). Propp concluded that all the stories studied had a similar structure the same in the sense of a story the actors and their properties can change but the actions and roles are the same. Propp also considers that a story has a construction. Construction consisting of motives has three elements, namely the perpetrators, deeds, and sufferers (Susanto, 2012: 111). The three elements are then grouped into two, namely the fixed element (deed) and the changed element (perpetrator and sufferer). In this relationship what is important is a fixed element (deed) that is the function itself (Rokmansyah, 2014: 92). Research conducted by Propp (Propp, 1968: 26-64) with the Russian fairy tale he studied produced 31 functions distributed into the symbol to facilitate the creation of the schematic in Table 1.

According to Propp that all 32 of these functions is the perfection of a story in which faithfully the functions in the story. But often not all of the functions contained in the story only contain a few parts. From the 32 functions, there are 7 speres of actions in it which are made by Propp, namely (1) villain: criminals who fight with heroes, (2) donors: donors giving something to heroes can be magical objects/ spells, (3) helper: helper who is directly involved helping the hero in completing his tasks, (4) princess and father: the princess and her father (king) give heavy tasks, the princess marries the hero, (5) dispatcher: the sender who sends the hero to complete his duty, usually a king, (6) hero: a hero defeats the enemy, (7) false hero: the false hero at the beginning pretending to help the hero at 
the end of the story turns out to be a villain (Propp, 1968: 79-80).

Table 1. Functions of Actors in the Actions of Vladimir Propp

\begin{tabular}{|c|c|c|}
\hline No. & Functions & Symbol \\
\hline 1 & Initial situation & $\mathrm{a}$ \\
\hline 2 & Absentation & $\beta$ \\
\hline 3 & Interdiction & $\gamma$ \\
\hline 4 & Violation & $\delta$ \\
\hline 5 & Reconnaissance & $\varepsilon$ \\
\hline 6 & Delivery & $\zeta$ \\
\hline 7 & Fraud & $\eta$ \\
\hline 8 & Involvement & $\Theta$ \\
\hline 9 & Crime & A \\
\hline 10 & Lack & $\mathrm{a}$ \\
\hline 11 & Mediation & B \\
\hline 12 & Action & $\mathrm{C}$ \\
\hline 13 & Departure & $\uparrow$ \\
\hline 14 & The first function of the donor & $\mathrm{D}$ \\
\hline 15 & The hero's reaction & $\mathrm{E}$ \\
\hline 16 & $\begin{array}{l}\text { Provision or receipt of a mag- } \\
\text { ical actor }\end{array}$ & $\mathrm{F}$ \\
\hline 17 & Spatial translocation & G \\
\hline 18 & Struggle & $\mathrm{H}$ \\
\hline 19 & Marking & $\mathrm{J}$ \\
\hline 20 & Victory & I \\
\hline 21 & Needs are fulfill & $\mathrm{K}$ \\
\hline 22 & Return & $\downarrow$ \\
\hline 23 & Pursuit & $\operatorname{Pr}$ \\
\hline 24 & Rescue & Rs \\
\hline 25 & Unrecognized arrival & $\mathrm{O}$ \\
\hline 26 & Unfounded claims & $\mathrm{L}$ \\
\hline 27 & The difficult task & M \\
\hline 28 & Solution & $\mathrm{N}$ \\
\hline 29 & Recognition & Q \\
\hline 30 & Exposure & Ex \\
\hline 31 & Transfiguration & $\mathrm{T}$ \\
\hline 32 & Punishment & $\mathrm{U}$ \\
\hline 33 & Marriage & W \\
\hline
\end{tabular}

There have been many studies examining Lampung's folklore, including research conducted by Zulkarnais et al (2018) with the research title "Educational Game Introduction to Lampung Folklore on the Android Platform", Rosmana (2010) with the title "Myths and Values in Lampung Folklore", Margaretha (2017) with the title "Analysis of Myth Classification in the Oral
Traditions of the Lampung Community", Aminah et al (2016) with the title "Educational Values of Lampung Oral Literature Books in Lampung Language Learning in Middle School."

Research must have novelty, that is the difference between the research that will be conducted and the research that has been done so that there are differences. Differences in the study and research-previous studies lie in the theories used to examine an object of study is the story and the story of the Batu Naga. Although both are from Lampung folklore, the objects are still different, so the results will be very different. There has never been a study examining folklore narrative Batu Naga using the theory of Vladimir Propp and there is no research that studies the story Batu Naga using any theory, so this research is very important to be carried out so that the Lampung People's story becomes a reading, not a neglected story.

Therefore the purpose of this research is to know the form of folklore in Lampung as well as to study it with the theory of narratology Vladimir Propp. Vladimir Propp studied the fairy tales in Russia and produced 32 functions that would be different if the theory was applied in traditional folklore, especially in Lampung, different results would be obtained because each story in each region has its uniqueness. The researcher wants to know how many functions are distributed in the action environment that is reflected in the scheme.

\section{METHOD}

This research is included in descriptive qualitative research that is a study that is poured in the form of words, not in the form of numbers. The data source for this research is a collection of stories in the book titled "Cerita Rakyat Daerah Lampung" number 14 with the title of the story "Pulau Tampat" published by the Ministry of Education and Culture in 1984. Data collection techniques using documentation techniques, namely collecting data in the form of books, notes, literature associated with the object to be analyzed through literature study.

Data analysis techniques used using the flow method by Miles and Huberman (2009, 1620), namely (1) data reduction, (2) data presentation, and finally (3) concluding. Data reduction is done by classifying which data is the main and 
not so that at any time it is easy to find again when the data is needed again. After reducing the data, then the data is presented by arranging the data into each group that is the focus of the research. The last step is drawing conclusions that still require verification so that the data obtained are truly valid.

Data analysis uses morphological analysis techniques developed by Vladimir Propp. The steps in the morphological analysis are (1) determining the function of the perpetrators in the story Batu Naga and then given the symbol according to those made by Vladimir Propp, (2) distributing the functions that exist into the action environment, (3) making a scheme based on functions perpetrator's actions.

\section{FINDINGS AND DISCUSSION}

\section{Findings}

The Batu Naga story originates from Kelumbayan Village, Tanggamus Regency, located in Lampung Province, precisely on Paku Beach. The story of the Batu Naga is told long ago in the village of Kelumbayan there were many ferns and then the surrounding community named the place Paku Beach. Because many ferns make the soil fertile so many people from other villages come to open fields and fields. They grow pepper, coffee, resin, cloves, and other trees.

Every time a new area is opened there will be challenges and obstacles such as the invasion of wild animals there are also large snakes that live in the forest often bite residents who pass. Even so, residents never back down despite many obstacles that prevented it. They continue to struggle to survive. Not only large snakes that make people afraid, but two more dragons also live on the seabed and often disturb the population. The villagers built a stronghold to repel the dragon by building a large bonfire and sounding cans so that dragons on the seabed did not dare to come to disturb the residents.

Years change, times change too. Formerly residents around the coast of Paku did not know God, then converted to Hindu-Buddhist and finally Islam. They are already familiar with Islam and their belief in superstitions is gradually diminishing. When the two dragons came out of the seabed, the residents no longer made camp- fires and sounded cans, but were replaced by the sound of the call to prayer.

Since the religion first Islam entered, residents worked together to build a mosque to worship, recite the Qur'an, listen to the sermon. Among other residents, there was a name called Ratu Ali who was very religious. He had performed the pilgrimage so that it was called Haji Ratu Ali. Ali's job was as a Qur'an teacher in a mosque, before living in Paku Beach he had lived in Betung as a Qur'an teacher. Ratu Ali is a great person, having powers that others do not have.

One night Ali dreamed of meeting an old grandfather. The grandfather's orders in his dream were for Ali to meditate in a cave to gain strength to help the villagers from the impending distress. At first, Ratu Ali did not believe in dreams, but that dream always came every night. The late morning, after Friday prayers Ali said goodbye to the family to go that meditate. His wife and children encourage Ratu Ali to return safely. Before leaving to meditate he said goodbye to children students' and looked for other Qur'an teachers so they did not feel disadvantaged.

Finally, Ratu Ali left in a cave near Paku beach, meditating for forty days and forty nights. Every night he goes through with hard struggle. When the fortieth night Ratu Ali was visited by his grandfather in his dream, the grandfather gave three items the size of coffee beans to be swallowed by Ratu Ali. After swallowing the coffee beans, Ratu Ali gained tremendous power. Whatever he says will become a reality. The grandfather's message that Ratu Ali was not arrogant, had to help villagers in need and Ratu Ali's hermitage to become a place of prayer as well as a well where Ratu Ali fell after being trained by his grandfather to be used as a place of ablution.

After finishing his hermitage, Ratu Ali returned home without arrogance. He always greets others when he meets on the street. Not long after the return of Ratu Ali, there came a demon king with his ship in the ocean making the villagers restless. With the power of Ratu Ali can make demon kingship to stone by his words.

Then came the two dragons who often bothered the population to challenge Ratu Ali, but the dragon was defeated by Ratu Ali's oath which made it a stone. Until now the stone is still there but over time it has been discharged with the waves so that its shape began to change. 


\section{Morphology of Folklore Batu Naga Lampung}

\section{Function Analysis}

There are several functions of the perpetrators' actions in the Batu Naga story and are equipped with symbols to facilitate the preparation in the Propp model as follows:

Needs are fulfill (K). In the past, Paku beach was overgrown with fern/nail trees, therefore residents called it Paku Beach. This fern is very fertile, so many people from other villages come to open fields. They grow pepper, coffee, cloves, resin, and other trees.

Fraud $(\eta)$. When the sea dragon came to disturb the inhabitants of the Paku coast, sounds were made from cans that we're able to produce very loud sounds and burn wood to make very large fires. This was done by residents to drive away sea dragons so as not to get close to shore.

Crime (A). There is one fear that most residents suffer. When big waves occur at night and coupled with rain come out from the bottom of the sea two tails. His body crept into the beach. Its venomous tongue is always ready to lick its prey. His eyes glowed like burning flames. The shape is very scary. If the situation is like that, people who are still at sea quickly move their boat to the nearest island.

Involvement $(\theta)$. In the past, the residents of the Paku beach did not know God. At first, entered the teachings of Hinduism, Buddhism then Islam. They can read the shahada and pray. Islam is rapidly developing, all the inhabitants of the coastal Paku and surrounding areas have converted to Islam. Since Islam entered, many residents were visited by the Qur'an teacher. Residents flock to build mosques and other places of worship. Then they learn to recite and listen to sermons.

Mediation (B). When Ratu Ali was asleep, he dreamed of meeting an old grandfather but he did not know him. The old grandfather ordered Ratu Ali to hold a hermitage after Friday prayers on the island of Tampat. The hermitage was carried out so that Ratu Ali gained strength to protect the island of Paku from his enemies such as the two dragons and the demon king who always disturbed the inhabitants of the Paku coast.

The difficult task (M). Old grandfather came to Ali's dream to tell him to meditate for 40 days without eating or drinking. Ali had to cross the beach to get to Tampat Island where he was imprisoned. Said old grandfather if Ali passed his toughest test, he could save his family, villagers and all those who needed his help.

Action (C). Every night Ratu Ali always dreams of meeting an old grandfather who tells him to go to meditate to save his family and the village where he lives. Therefore, Ali decided to go carry out his asceticism.

Marriage (W). Ratu Ali decides to carry out his grandfather's orders for him to go to meditate. Before leaving, Ali said goodbye to his children and wife to ask for a blessing so that he could return safely and in the protection of God.

Departure ( $\uparrow)$. Ratu Ali left the house after Friday prayers. He said goodbye to his wife and children that he would go to the island. Also, he said goodbye to all the students in his village. He has also replaced the Qur'an teacher so that his students do not feel disadvantaged.

Reconnaissance ( ). Arriving at the predetermined island, Ratu Ali started looking for a safe place. After all the places explored the island turned out to be full of bats and seabirds. In a protected place that looked like a big rock, he went there and set the stone he found as a hermitage.

The first function of the donor (D). On the thirty-eighth night, strong winds came. Many tree branches were broken, the sea waves were howling, bats coming out of their nests, the air was getting cold. Between conscious and not, Ali was visited by parents who had met him in a dream first and then gave a magical object and was thrown into Ali's mouth, after swallowing it, Ali's feelings began to change.

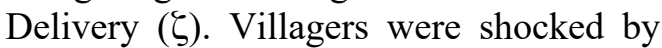
the strange object that fell onto the beach. The object was flown from the island. At that time people began to realize that Ratu Ali had gone to meditate on the island. The customary leader together with the residents prayed to Allah to keep Ratu Ali safe at home.

Provision or receipt of a magical actor (F). About eleven o'clock in the afternoon, residents in the village hall were shocked by the sound of strange objects falling on the beach. This thing was blown by the wind from the island to the beach. Many times this thing floated in the air. All residents see strange objects that fly in the air from morning to evening. It feels like people 
want to reach it, but it's very tall. It turns out that the thing that can fly during the day is Ratu Ali.

Unrecognized arrival $(\mathrm{O})$. People who can go to the beach cannot do the same thing as Ratu Ali can fly here and there. Ratu Ali himself did not know who could fly.

Spatial translocation (G). Night came and all the residents were fussed over by an artificial well that suddenly existed. The well was made from the fall of Ratu Ali at Paku beach when he was trained to unconsciously fly by an old grandfather. Different kinds of responses from the population, all have interpretations and make their own stories about the well. Because it was going to rain, many residents returned home and did not continue the conversation.

Lack (a). At Ratu Ali's house, her family is busy praying for Allah protection. The rain fell very hard so that his family's anxiety increasingly peaked.

The hero's reaction (E). Last night his hermitage Ratu Ali dreamed of meeting the old grandfather again. The old grandfather said that Ali could jump very far, his strength was like the power of ten elephants. When Ali can fly during the day, it is training from the old man to himself. Now Ali's mouth is poisonous, whatever he says can come true. Under Ali's chin, there was an amulet wrapped in a white cloth and tied around his waist.

Solution (N). Ratu Ali can carry out the hermitage ordered by the old man for 40 days. Ali awoke from his hermit, he did not sleep again. Then, Ali decided to go home.

Return $(\downarrow)$. By dawn, he packed up to go home, one jump until he went to Paku beach. Upon arrival in front of the house, Ali said his greetings and after being answered by his wife the door was opened. Wife and happy to see Ratu Ali returned.

Marking (J). After a short rest after returning from meditating for 40 days. Ali came out of the house on the street and he reprimanded his acquaintances first, but every person he encountered became difficult. Ali was surprised he forgot to release his talisman.

Exposure (Ex). After Ratu Ali's return from his hermit, he held a meeting with the residents of the nail beach. Ratu Ali conveys everything he can get into hermitage. Since then Ratu Ali has become increasingly respected and respected.
Struggle $(\mathrm{H})$. Ratu Ali did hermitage again to the first island he did hermitage. The demon king comes with his ship which is big and majestic. The demon king aims to tempt Ratu Ali to fail in her task. Ratu Ali remembers the words spoken by the old grandfather that his mouth is venomous, whatever he says comes true. Then Ratu Ali fought against the demon king with the power he possessed.

Punishment (U). Of Satanic king disturbs the hermitage of Ratu Ali for the second time so that Ratu Ali fails. The demon king often disturbs the inhabitants, finally, Ratu Ali takes the oath and his ship becomes a stone forever. Until now the stone is still there and is called the "Queen Ship."

Pursuit (Pr). Family The king of demons feels vengeful towards Ratu Ali. Until now, if there is a boat that passes this island is often disturbed by demons. Therefore the passenger said that he was the grandson of Ratu Ali. Hearing this, demons became afraid of being cursed by Ratu Ali.

Victory (I). When Ratu Ali was doing hermitage again, came two sea dragons who want to come to tempt the population, all residents worried. The sound of the call to prayer echoed in all directions to drive away from the dragon but failed. The two dragons continued to rage, Ratu Ali swore by defeating the two raging dragons.

Transfiguration (T). Two dragons rampage on Paku beach. The villagers were afraid of the dragon tantrums. Because the two dragons continued to rage, Ratu Ali with his oath had succeeded in defeating the two raging dragons. The two dragons were cursed to stone. Until now the two dragon stones are still there and are given the name "Dragon Stone".

\section{Distribution of Functions in the Environmental Action}

The functions contained in every story are not always the same, not all functions are present. According to Propp (1968: 79-80), the 32 functions found can be distributed into 7 action environments. Folklore Batu Naga only contains 26 functions that can be distributed into 6 action environments, namely (1) criminal action environment, criminals who fight directly with criminals including A, H, U, Pr, T.; (2) action environment Donor, the act of giving magical items 
ferent generations and the speakers are also different, therefore there are different versions of the stories from one another but the core of the story remains the same and is conveyed. The essence of the story is the same, for example, a villain will be defeated by a hero, a princess saved by a prince and then married, the hero gets a heavy-duty like asceticism.

From the results of studies that have been done, they have never found the same number of actors and environmental functions of action. Research conducted by (Sriyono, 2014) found 17 functions of actors and 5 action circles in the story of Papua, (Alaini, 2014) researched Sumbawa folklore with the result that there were 14 perpetrators' functions distributed into 5 action environments, (Maulina, 2014) found 16 functions in Riau folklore, (Widianti \& Indiatmoko, 2018) conducted a study of Cirebon folklore with the results found as many as 17 functions of actors and 5 functions of environmental action. This shows that traditional folklore especially those in Indonesia are diverse and unique. The functions in each story are a series of events, the more functions there are the more diverse the culture of the people.

\section{Distribution of Functions in the Environmental Action}

There are 6 action environments contained in Lampung Batu Naga folklore, namely the environment of the actions of criminals, donors, helpers, daughters-fathers, senders, and heroes. Function offenders who distributed into the environment is a criminal act of two dragons and demon king with the function of offenders (A), struggle $(\mathrm{H})$, pursuit $(\mathrm{Pr})$, penalties $(\mathrm{U})$, changes in such (T). The function of the perpetrators of crimes (A) is carried out by the dragon when it comes out of the seabed to frighten the inhabitants of Paku beach by spitting fire from inside its mouth. Not only dragons become criinals, but there is also a demon king who comes to tempt Ratu Ali but can be defeated by Ratu Ali's (H) struggle. After the defeat of the demon king was overtaken by the defeat of the two dragons that were punished $(\mathrm{U})$ by the curse of Ratu Ali who made the transfiguration (T) into stone. The characters in the story Batu Nga who enter into the function of the perpetrators are two dragons and a demon king who always comes to disturb the population and can even prey on humans.
The second environment of action is that the donor includes the first function of a helper (D) and a prescription from a dukun/ paranormal (F). A benefactor is an old man who can provide guidance, advice and magical objects to Ratu Ali. In his hermitage, on the thirty-eighth day, Ratu Ali was visited by an old grandfather who always came in his dreams every night. The grandfather came to give three coffee beans that were swallowed by Ratu Ali, with that power Ratu Ali could fly high and have very powerful nails.

The third environment of action is a helper action including deception $(\eta)$ and removal of space $(G)$. When two sea dragons come to the surface, all residents of Paku Beach are very scared. They all make tools that can be used to repel the presence of sea dragons by ringing cans, making large fires to frighten dragons that will prey on residents. The figure in the environment of the helper action is the residents of Paku Beach village.

The fourth action environment is the environment of the actions of the daughter and father including marriage (W) and needs (a). It is said that Ratu Ali is married and has one child, but it is not yet known where his wife and son are from. Because Ratu Ali often dreamed of being met by an old grandfather who told him to be imprisoned to gain strength, then he left for an island. His departure was worried by his wife and child who were not willing to see a husband and a father leave for a few days to meditate.

The fifth action environment is the sender covering fulfilled needs (K), involvement (D), mediation (B), and delivery ( $\zeta)$. Those involved in the environment of the sender's actions are the elderly grandfather, residents and customary leaders. Many residents live in the Paku area because the land is very fertile and cool, some of them open rice fields, fields to plant coffee, cloves, rice, and other trees. But the beliefs of the population are animism and dynamism. They still believe in superstition, myth, worshiping trees, worshiping stones. So the teacher came to recite the Paku beach to teach Islam and renounce their previous beliefs. Therefore, the spread of Islam in Paku Beach until the residents set up mosques, recite Qur'an, listen to lectures.

The sixth circle of action is the environment of hero action including the functions of the heavy-duty performer (M), action starts (C), 
departure $(\uparrow)$, reconnaissance ( ), unidentified $(\mathrm{O})$, reaction of hero $(\mathrm{E})$, solution $(\mathrm{N})$, homecoming $(\downarrow)$, marking $(J)$, exposure (Ex), and victory (I) The hero in the Batu Naga story is Ratu Ali, a very religious person as well as a Qur'an teacher. Ratu Ali gained strength from meditation on an island called Tampat island. His hermitage was not without reason and command but he was ordered by the old grandfather to be a meditation for forty days and forty nights so that he would gain strength to defeat the dragon and the demon king who always bothered the inhabitants.

This research is different from Embram's (2016) study which examines the folklore of Malind Anim Kanume that in his research the villain is the tribe Yanime which means humans, while in the story Batu Naga the villain is the dragon and king demon. That way anyone in the story will not reduce the meaning and uniqueness of the story. In terms of structure, events and characters in the story even seem unreasonable (Lestari, 2015: 40). Propp stated that a story has a construction consisting of motives divided into three elements, namely actions, actors and sufferers. These three elements can be grouped into two parts, namely the fixed element is the act and the changed element is the actor/action. The fixed and changing element for Propp is the most important fixed element (Fajrin, 2014: 196).

\section{Scheme Functions}

Functions in stories created by Propp are used to make story schema easier. Many good stories from myths, legends, fairy tales, movies, only contain a few functions. From these functions, Propp gives a special symbol and mark to each function to facilitate the creation of a story/plot scheme (Hasan, 2018: 134). The Batu Naga story pattern is different from the story pattern studied by Embram (2015) which has many story patterns, there are 5 story patterns while the story is Batu Naga found in two-story.

The story is Batu Naga illustrated by two patterns of movement in the story. The first movement tells the story of the coastal village of Paku which thrives, a lot of people farming, farming, they grow coffee, pepper, rice, cloves. They lived peacefully and calmly, but that calm turned to terrible when two dragons came from the bottom of the sea to disturb the population and prey on humans. There was one person who was ordered to be imprisoned to gain strength to be able to beat Naga Laut namely Ratu Ali. Then he imprisoned for forty days and forty nights on the island of Tampat and managed to resist the temptation by returning home already to have the strength he was looking for.

The second move when Ratu Ali fought the two dragons and his revenge was the demon king. He transformed two dragons and a demon king into stone. Until now the two stones are still in the village of Paku Beach, but the shape is not as before due to the big waves. It can be concluded that the story of Batu Naga has a plot forward because every event tells the future.

\section{CONCLUSION}

Batu Naga Lampung folklore is a story that is believed to be still developing today. Traces of the story in the story still exist, even though the form is not as it was before because of changing times. Vladimir Propp's narcological theory can not only be used to study Russian fairy tales, but Lampung folklore can also be studied with Propp's theory. The story of Batu Naga is a dragon that has an evil nature, likes to disturb the villagers of Pantai Paku. As a result, the dragon was cursed by Ratu Ali, he gained strength starting from the dream of meeting an old grandfather who ordered to conduct meditation on the island for forty days and forty nights.

The results of research on the folklore Batu Naga Lampung with Vladimir Propp's theory found 26 functions, namely fulfilled needs, deception, crime, involvement, mediation, heavy-duty, starting action, marriage, departure, reconnaissance, first function helper, sending, prescription from shaman, unrecognized arrivals, displacement of space, needs, reactions of heroes, solutions, return, markings, exposure, struggle, punishment, pursuit, victory, and transfiguration. All functions have symbols such as $\mathrm{K}, \eta, \mathrm{A}, \theta, \mathrm{B}, \mathrm{M}, \mathrm{C}, \mathrm{W}, \uparrow, \quad, \mathrm{D}, \zeta, \mathrm{F}, \mathrm{O}, \mathrm{G}, \mathrm{a}, \mathrm{E}$, $\mathrm{N}, \downarrow, \mathrm{J}, \mathrm{Ex}, \mathrm{H}, \mathrm{U}, \mathrm{Pr}, \mathrm{I}, \mathrm{T}$. Twenty-six functions were found to enter into six action environments namely criminals, donors, helpers, sons and fathers, senders and heroes. 


\section{REFERENCES}

Abrams, M.H. (2009). A glossary of literary terms. Ninth Edition. USA: Wadsworth Cengage Learning.

Alaini, N. N. (2014). Struktur naratif cerita rakyat Sumbawa Barat. Jurnal Atavisme, 17(2), 240253, http://dx.doi.org/10.24257/atavisme. v17i2.13.240-253

Aminah, N.A., Eko, N. \& Sanusi, E. (2016). Nilai pendidikan buku sastra lisan Lampung dalam pembelajaran bahasa Lampung di SMP. Jurnal Tiyuh Lampung, 1(1), 1-15.

Anderson, G. (2006). Greek and roman folklore. USA: Greenwood Press.

Bal, M. (1999). Narratology: Introduction to the theory of narrative. 2nd Editor Toronto: Toronto University Press.

Embram, E.R. (2016). Morfologi cerita rakyat Malind Anim Kanume. Jurnal Kadera Bahasa, 8(1), 123-131, https://doi.org/10.26499/kc. v12 i2. 184

Endraswara, S. (2013). Folklor nusantara: Hakikat, bentuk, dan fungsi. Yogyakarta: Penerbit Om-bak.

Fajrin, H. (2014). Gonggang ri sadoqkoq: Morfologi cerita rakyat Vladimir Propp. Jurnal Sawerigading, 20(2), 195-203.

Gayatri, S. (2009). Struktur naratif cerita Anggun Nan Tongga: Pendekatan Vladimir Propp. Jurnal Linguistika Kultura, 3(1), 46-55, https: // doi.org/10.26499/kaba.v8i1.25

Hamik, Z. (2018). Struktur dan nilai-nilai kultural cerita Randa Wula'a. Jurnal Sawerigading, 21(1), 11-20, http://dx.doi.org/10.26499/ sawer.v24i1.253

Hasan, N.H. (2018). Cerita rakyat Nenek Luhu: Tinjauan Vladimir Propp. Jurnal Metasastra, 11(2), 131-144, http://dx.doi.org/10. 26610/metasastra.2018.v11i2.131-144

Haviland, W A. (1988). Anthropology: Jilid 2. Pen. R.G. Soekadijo. Jakarta: Erlangga.

Lestari, U.F.R. (2015). Morfologi cerita rakyat Arso Watuwe: Sebuah analisis naratologi Vladimir Prop. Jurnal Metasastra, 8(1), 139-154, Doi: http://dx.doi.org/10.26610/metasastra.2015. v8i1.139-154

Maneerat, J. \& Wilailak O. (2012). Folklore, restoration of social capital and community culture. Procedia-Social and Behavioral Science, 65, 218-224, http://dx.doi.org/10.1016/j.sbspro. 2012.11.114.

Margaretha, R. (2017). Analisis klasifikasi mitos dalam tradisi lisan masyarakat Lampung. Jurnal Pendidikan Progresif, 7(2), 117-126, http: //dx.doi.org/10.23960/jpp.v7.i2.201715

Maulina, Y. (2014). Cerita rakyat "Asal-usul pulau halang": Analisis fungsi Vladimir Propp. Jurnal Madah, 5(1), 105-114, http://dx.doi. org/10.31503/madah.v5i1.528

Miles, B. M. \& Michael, H. (2009). Analisis data kualitatif: Buku sumber tentang metodemetode baru. Diterjemahkan oleh Tjetjep Rohendi Rohidi. Jakarta: Universitas Indonesia Press.

Nursa'ah. (2014). Inverntarisasi cerita rakyat di Kabupaten Banjarnegara. Jurnal Sutasoma, 3(1), 49-56, http://doi.org/10.15294/ sutasoma.v3i1.4031

Propp, V. (1968). Morphology of folktales. Austin and London: University of Texas Press.

Putra, N.R.A. \& Sri, W. (2017). "Analisis cerita rakyat Jaka Tingkir: Kajian struktural naratif Vladimir Propp." CARAKA: Jurnal Ilmiah Kebahasaan, Kesastraan dan Pemelajarannya, 4(1), 122-129.

Ratna, N.K. (2015). Teori, metode, dan teknik penelitian sastra. Yogyakarta: Pustaka Pelajar.

Rokmansyah, A. (2014). Studi dan pengkajian sastra: perkenalan awal terhadap ilmu sastra. Yogyakarta: Graha Ilmu.

Rosmana, T. (2010). Mitos dan nilai dalam cerita rakyat masyarakat Lampung. Jurnal Patanjala, 2(2), 191-206, http://dx.doi.org/10. 30959/patanjala.v2i2.215

Sarwono, S.W. (2016). Psikologi lintas budaya. Jakarta: PT Raja Grafindo Persada.

Sehandi, Y. (2014). Mengenal 25 Teori Sastra. Yogyakarta: Penerbit Ombak.

Sriyono. (2014). Morfologi sastra lisan tobati. Jurnal Metasastra, 7(2), 215-226, http://dx.doi.org/ 10.26610/metasastra.2014.v7i2.215-226

Susanto. D. (2012). Pengantar teori sastra: dasardasar memahami fenomena kesusastraan, psikokologi sastra, strukturalisme, formalisme rusia, marxisme, interpretasi dan pembaca, dan pascastrukturalisme. Jakarta: Caps.

Widiati, N. \& Bambang, I. (2018). Narrative structure of babad Cirebon: Vladimir Propp analysis. Jurnal Seloka: Jurnal Pendidikan Bahasa dan Sastra Indoneisa, 7(1), 67-76, https://doi. org/10.15294/seloka.v7i1.17602

Zulkarnais, A., Purwono, P. \& Adi, S. (2018). Game edukasi pengenalan cerita rakyat Lampung pada platform android. Jurnal Informatika: Jurnal Pengembangan IT, 3(1), 96-102, http://dx.doi.org/10.30591/jpit.v3i1.621 